\title{
Clitocybin A, a Novel Isoindolinone, From the Mushroom Clitocybe aurantiaca, Inhibits Cell Proliferation Through G1 Phase Arrest by Regulating the PI3K/Akt Cascade in Vascular Smooth Muscle Cells
}

\author{
Kyu-Dong Yoo ${ }^{1, \dagger}$, Eun-Seok Park ${ }^{1, \uparrow}$, Yong Lim² ${ }^{2}$, Shin-Il Kang ${ }^{1}$, Su-Hyang Yoo ${ }^{1}$, Ha-Hee Won ${ }^{1}$, \\ Young-Hee $\mathrm{Kim}^{3}$, Ick-Dong $\mathrm{Yoo}^{3}$, Hwan-Soo Yoo ${ }^{1}$, Jin Tae Hong ${ }^{1}$, and Yeo-Pyo Yun ${ }^{1, *}$ \\ ${ }^{1}$ College of Pharmacy, Research Center for Bioresource and Health, Chungbuk National University, \\ Cheongju 361-763, Korea \\ ${ }^{2}$ Department of Clinical Laboratory Science, Dong-eui University, Busan, Korea \\ ${ }^{3}$ Chemical Biology Research Center, Korea Research Institute of Bioscience and Biotechnology, Daejeon, Korea
}

Received August 28, 2011; Accepted November 29, 2011

\begin{abstract}
Abnormal proliferation of vascular smooth muscle cells (VSMCs) plays an essential role in the pathogenesis of vascular diseases, such as atherosclerosis, hypertension, and restenosis. Clitocybin A, a novel isoindolinone, isolated from the culture broth of mushroom Clitocybe aurantiaca has been reported to possess free radical scavenging activity. However, the antiproliferative effects of clitocybin A on VSMCs are unknown. In the present study, we investigated the effect of clitocybin A on platelet-derived growth factor (PDGF)-BB-induced proliferation of VSMCs and examined the molecular basis of the underlying mechanism. Clitocybin A inhibited DNA synthesis and cell proliferation. In accordance with these findings, clitocybin A blocked the PDGF-BB-inducible progression through $\mathrm{G} 0 / \mathrm{G} 1$ to $\mathrm{S}$ phase of the cell cycle in synchronized cells and decreased the expression of cyclin-dependent kinase (CDK) 2, CDK4, cyclin D1, cyclin E, and proliferative cell nuclear antigen. In addition, clitocybin A inhibited the PDGF-BB-induced phosphorylation of phosphatidylinositol 3 kinase (PI3K) / Akt kinase. However, clitocybin A did not change the expression levels of extracellular signal-related kinase (ERK) 1/2, phospholipase $\mathrm{C}-\gamma 1$, and PDGF-R $\beta$ phosphorylation. These results indicate that clitocybin A may inhibit VSMCs proliferation through G1 phase arrest by regulating the PI3K/Akt pathway.
\end{abstract}

Keywords: clitocybin A, vascular smooth muscle cell, platelet-derived growth factor (PDGF)-BB, PI3K/Akt pathway

\section{Introduction}

Vascular smooth muscle cells (VSMCs) proliferation within the intimal layer of the vessel wall is a key step in atherosclerotic plaque development (1). Vascular injury can induce cytokines such as interferon- $\gamma$ and interleukin 1 and growth factors such as platelet-derived growth factor (PDGF) and basic fibroblast growth factor (bFGF). These factors stimulate VSMC proliferation by regulation of downstream signal transduction such as the mito-

\footnotetext{
These authors equally contributed to this study.

*Corresponding author. ypyun@chungbuk.ac.kr

Published online in J-STAGE

doi: 10.1254/jphs.11159FP
}

gen-activated protein kinase (MAPK) pathway and the phosphatidylinositol 3 kinase (PI3K) / Akt pathway (2). PDGF-BB-stimulated VSMCs synthesize and excrete extracellular matrix components and collagen, which lead to neointimal thickening and restenosis.

PDGF-BB-induced proliferation and mitogenesis of VSMCs are prerequisites of intimal thickening, which is invariably observed after angioplasty (3). The binding of PDGF-BB to the PDGF receptor (PDGF-R) can activate three major signal transduction pathways including PI3K/ Akt, phospholipase C (PLC)- $\gamma 1$, and extracellular regulated kinase 1/2 (ERK1/2) $(4,5)$. Once PDGF binds to PDGF-R in VSMCs, PI3K is then activated, followed by the stimulation of Akt. The phosphorylation level of $\mathrm{PI} 3 \mathrm{~K} / \mathrm{Akt}$ is increased in cell proliferation and survival 
of VSMCs from thoracic aortas of male Sprague-Dawley rats and human VSMCs $(6,7)$.

Cell proliferation is regulated primarily by the cell cycle, which consists of $\mathrm{G} 0 / \mathrm{G} 1, \mathrm{~S}, \mathrm{G} 2$, and $\mathrm{M}$ phases. The G1 to $\mathrm{S}$ transition in cell cycle progression is controlled by the action of cyclin-dependent kinases (CDKs) and their activating subunits, the cyclins $(8,9)$. Complexes of cyclin D1-CDK4 and cyclin E-CDK2 predominantly act in sequence during the G1/S transition (10).

Recently, clitocybin A, novel isoindolinone, was isolated from the mushroom Clitocybe aurantiaca (11), and this compound inhibited reactive oxygen species (ROS)induced cell death by reducing the activation of caspase 3 and 9 , cytochrome $c$ release from mitochondria, and $\mathrm{NF}-\kappa \mathrm{B}$ activation in IMR-90 lung fibroblast cells (12). It suggests that clitocybins are novel ROS scavengers that can protect cells from apoptosis.

However, the effect of clitocybin A on VSMCs proliferation has not been clearly demonstrated. We attempted to elucidate the antiproliferative activity and machinery targets of clitocybin A in the PDGF-BB-induced signaling pathway. These results provide evidence that clitocybin A can inhibit proliferation and cell cycle progression via cell cycle-related proteins by regulating the PI3K/ Akt pathway.

\section{Materials and Methods}

\section{Materials}

Clitocybin A was synthesized and characterized as previously described (12) (Fig. 1A). It was dissolved in dimethylsulfoxide (DMSO) and added to Dulbecco's modified Eagle's medium (DMEM) with a maximum final DMSO concentration of $0.05 \%$. The cell culture materials were obtained from Gibco-BRL (Rockville, MD, USA), and other chemical reagents were from Sigma Chemical Co. (St. Louis, MO, USA). $\left[{ }^{3} \mathrm{H}\right]$ Thymidine was purchased from Amersham Pharmacia Biotech (Buckinghamshire, UK). PDGF-BB was purchased from Upstate Biotechnology (Lake Placid, NY, USA). Polyclonal antibodies specific for phospho-ERK1/2, phosphoAkt, phospho-PLC- $\gamma 1$, phospho-PDGF-R $\beta$, ERK1/2, Akt, PLC- $\gamma 1$, and PDGF-R $\beta$ were supplied by Cell Signaling Technology Inc. (Beverly, MA, USA). PCNA, cyclin D1, cyclin E, CDK2, and CDK4 antibodies were obtained from Santa Cruz Biotechnology, Inc. (Santa Cruz, CA, USA). All other chemicals were of analytical grade.

\section{Cell culture}

Rat aortic VSMCs were isolated by enzymatic dispersion using a slight modification of the method reported
(A)<smiles>O=C1c2cc(O)cc(O)c2CN1c1ccc(O)cc1</smiles>

(B)

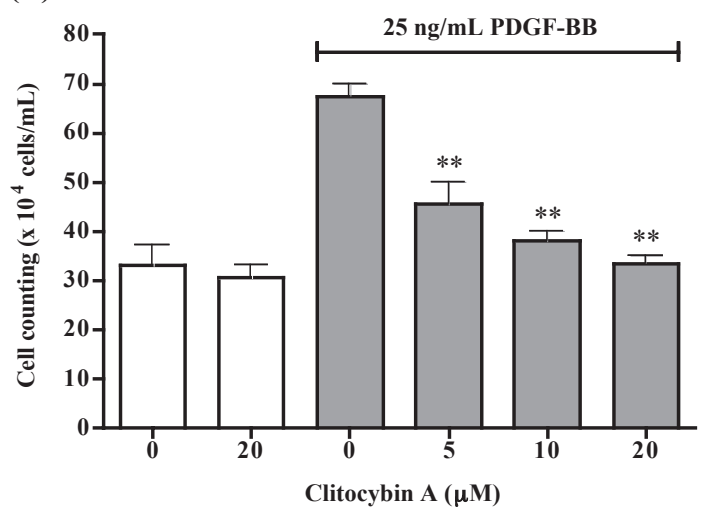

Fig. 1. Inhibitory effect of clitocybin A on PDGF-BB-stimulated cell proliferation. A: Chemical structure of clitocybin A. B: VSMCs were cultured in serum-free medium for $24 \mathrm{~h}$; treated with clitocybin A at $0,5,10$, and $20 \mu \mathrm{M}$ for $24 \mathrm{~h}$; and then stimulated by $25 \mathrm{ng} / \mathrm{mL}$ PDGF-BB for $24 \mathrm{~h}$. The cells were trypsinized and counted using a hemocytometer. Data represent the mean \pm S.E.M. from 4 different sets of experiments. $* * P<0.01$ vs. VSMCs stimulated with PDGFBB alone.

by Chamley (13). Cells were cultured in DMEM supplemented with $10 \%$ fetal bovine serum (FBS), $100 \mathrm{U} / \mathrm{mL}$ penicillin, $100 \mathrm{~g} / \mathrm{mL}$ streptomycin, $8 \mathrm{mM}$ HEPES, $2 \mathrm{mM}$ L-glutamine at $37^{\circ} \mathrm{C}$ in an incubator with a humidified atmosphere of $95 \%$ air and $5 \% \mathrm{CO}_{2}$. The purity of rat VSMCs culture was confirmed by western blotting of $\alpha$-smooth-muscle actin. The passage of VSMCs used in this experiment was $5-8$.

\section{Cell proliferation and DNA synthesis}

The cell proliferation and DNA synthesis of VSMCs were measured as described previously (14). In brief, VSMCs were seeded into 12-well culture plates at $4 \times 10^{4}$ cells $/ \mathrm{mL}$ with DMEM containing $10 \%$ FBS. Cells were incubated at $37^{\circ} \mathrm{C}$ for $24 \mathrm{~h}$. The medium was then replaced by serum-free medium in the presence or absence of clitocybin A. The cells were stimulated with $25 \mathrm{ng} / \mathrm{mL}$ PDGF-BB and then trypsinized with trypsin-EDTA. Cells were counted using a hemocytometer under a microscope. For the $\left[{ }^{3} \mathrm{H}\right]$ thymidine incorporation experiments, VSMCs were seeded and cultured for $20 \mathrm{~h}$ in 24-well culture plates under the same conditions as the ones in the cell proliferation assay. $\left[{ }^{3} \mathrm{H}\right]$ Thymidine $(1$ 
$\mu \mathrm{Ci} / \mathrm{mL}$ ) was then added to the medium and the cells were incubated further for $4 \mathrm{~h}$. The cultures were then placed on ice and reactions were terminated by aspiration of the medium, followed by sequential washes with PBS containing $10 \%$ trichloroacetic acid and ethanol/ether $[1: 1, \mathrm{v} / \mathrm{v}]$. Acid-insoluble $\left[{ }^{3} \mathrm{H}\right]$ thymidine was lysed with $300 \mu \mathrm{L}$ of $0.5 \mathrm{~N} \mathrm{NaOH}$, and the lysate was mixed with 3 $\mathrm{mL}$ scintillation cocktail (Ultimagold; Packard Bioscience, Meriden, CT, USA) and quantified using a liquid scintillation counter (LS3801; Beckman, Düsseldorf, Germany).

\section{Cell cycle progression analysis}

To estimate the proportion of cells in the various phases of the cell cycle, cellular DNA contents were measured by flow cytometry. Cells were harvested, fixed in $70 \%$ ethanol, and stored at $-20^{\circ} \mathrm{C}$. The cells were then washed twice with ice-cold PBS and incubated with RNase and propidium iodide (PI). Cell cycle phase analysis was performed using the FACSCalibur (BD Biosciences, San Jose, CA, USA) and the proportion of cells within the G1, S, and G2/M phases was analyzed with ModFit LT V2.0 (Verity Software House, Topsham, ME, USA).

\section{Western blot analysis}

The immunoblotting of VSMCs was performed as previously described (14). Briefly, VSMCs were seeded into 6-well culture plates at a density of $1 \times 10^{5}$ cells $/ \mathrm{mL}$ and then cultured in DMEM containing $10 \%$ FBS at $37^{\circ} \mathrm{C}$ for $24 \mathrm{~h}$. When cells reached up to $70 \%$ confluence, the medium was replaced with serum-free medium, and the cells were incubated for $24 \mathrm{~h}$. The medium was then changed to serum-free medium containing various concentrations of clitocybin $\mathrm{A}$, and the cells were incubated for $24 \mathrm{~h}$. VSMCs were stimulated with $25 \mathrm{ng} / \mathrm{mL}$ PDGF$\mathrm{BB}$ for $1 \mathrm{~min}$ for PDGF-R $\beta, 5 \mathrm{~min}$ for ERK $1 / 2$ and PLC- $\gamma 1,15$ min for PI3K and Akt phosphorylation assays. For the assay of cyclin D1, cyclin E, CDK2, CDK4, and PCNA expressions, VSMCs were stimulated by PDGF-BB $(25 \mathrm{ng} / \mathrm{mL})$ for $24 \mathrm{~h}$. The cell pellets were lysed, and the proteins were separated on $10 \%-15 \%$ SDS-PAGE. The proteins were transferred to PVDF membranes (Amersham Pharmacia Biotech). The membranes were then incubated with a 1:1000 dilution of the following antibodies: phospho-PDGF-R $\beta$, phosphoERK1/2, phospho-Akt, phospho-PI3K, phospho-PLC- $\gamma 1$, PDGF-R $\beta$, ERK1/2, Akt, PI3K, PLC- $\gamma 1$, PCNA, CDK2, CDK4, cyclin $\mathrm{D}_{1}$, and cyclin $\mathrm{E}$. The blots were washed with TBS/T and then incubated with a 1:5000 dilution of horseradish peroxidase-conjugated IgG secondary antibody (New England Biolabs, Beverly, MA, USA). The proteins were detected using an ECL plus kit (Amersham
Pharmacia Biotech), followed by exposing the membranes to Hyperfilm ECL (Amersham Pharmacia Biotech). The band intensities were quantified using ScionImage Software.

\section{Statistical analysis}

The experimental results are expressed as the mean \pm S.E.M. One-way analysis of variance (ANOVA) was used for multiple comparison followed by Dunnett's test. $P$-values $<0.05$ and $<0.01$ were considered significant.

\section{Results}

Effect of clitocybin A on VSMCs proliferation

Direct cell counting was performed to determine whether clitocybin A inhibited PDGF-BB-stimulated VSMCs proliferation. Treatment of VSMCs with $25 \mathrm{ng} /$ $\mathrm{mL}$ PDGF-BB for $24 \mathrm{~h}$ increased the number of cells from $33.0 \times 10^{4}$ to $67.5 \times 10^{4}$ cells/well. Treatment with both PDGF-BB and 5, 10, or $20 \mu \mathrm{M}$ clitocybin A for 24 $\mathrm{h}$ decreased the number of cells to $45.5 \times 10^{4}, 38.0 \times 10^{4}$, or $33.5 \times 10^{4}$ cells/well, in a concentration-dependent manner, compared to treatment with PDGF-BB alone (Fig. 1B).

\section{Effects of clitocybin A on DNA synthesis and cell cycle progression}

To investigate the effects of clitocybin A on DNA synthesis in VSMCs, we performed a $\left[{ }^{3} \mathrm{H}\right]$ thymidine incorporation assay. The incorporation of $\left[{ }^{3} \mathrm{H}\right]$ thymidine into DNA was found to be significantly increased by adding PDGF-BB to VSMCs, and clitocybin A significantly inhibited $\left[{ }^{3} \mathrm{H}\right]$ thymidine incorporation into DNA in a concentration-dependent manner (Fig. 2A). Inhibition percentages were $49.5 \%, 72.2 \%$, and $84.0 \%$ at concentrations of 5,10 , and $20 \mu \mathrm{M}$, respectively.

As shown in Fig. 2B, the serum-deprivation of VSMCs for $24 \mathrm{~h}$ resulted in an approximately $92.36 \%$ synchronization of the cell cycle at the G0 phase, and PDGF-BB treatment of the VSMCs increased the percentage of cells in the S phase from $2.18 \%$ to $15.98 \%$. Clitocybin A diminished the PDGF-BB-stimulated cell cycle progression in a concentration-dependent manner: approximately $15.98 \%$ of the S phase shown in PDGF-BB-treated cells reduced gradually to the levels of $11.7 \%, 7.5 \%$, and $5.0 \%$ in the presence of 5,10 , and $20 \mu \mathrm{M}$ clitocybin A, respectively. Additionally, clitocybin A inhibited the phosphorylation of PCNA, which regulates the G1 to $\mathrm{S}$ phase transition in the cell cycle (Fig. 2C). This result suggests that clitocybin A is effective against DNA synthesis during the early events of the cell cycle. 

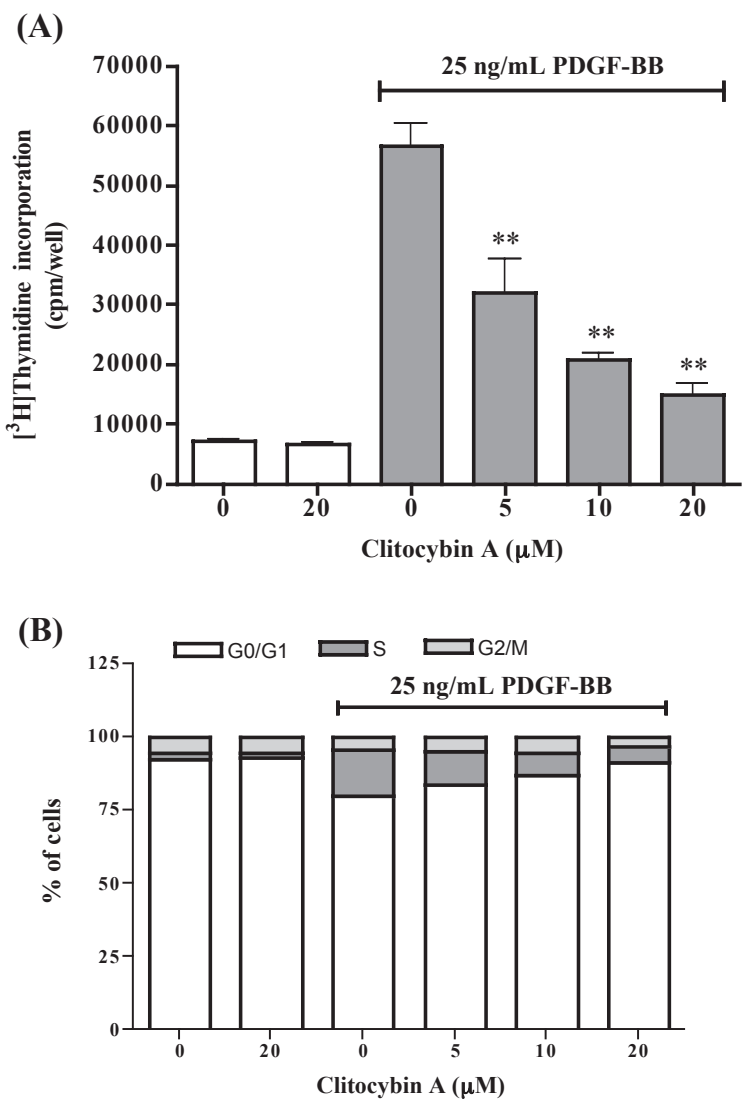

(C)
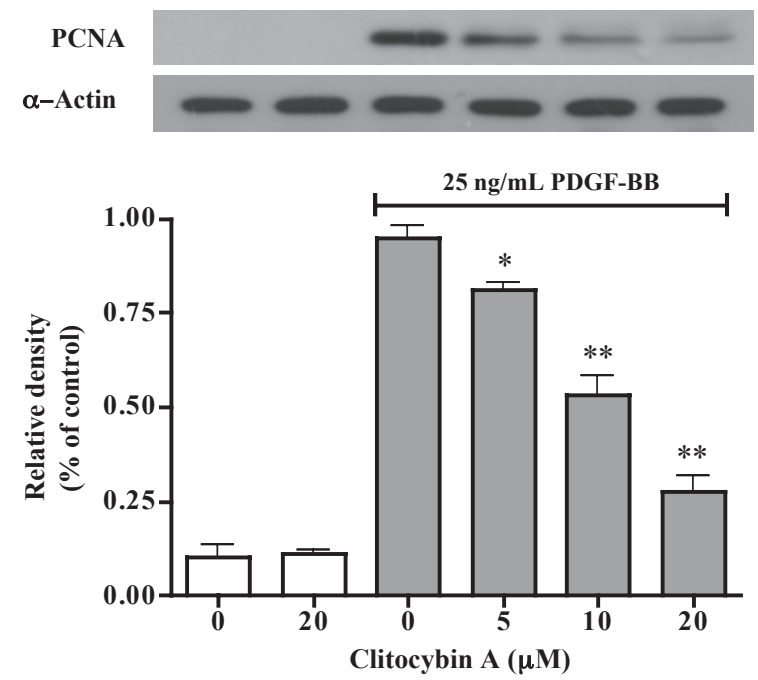

Fig. 2. Effects of clitocybin A on $\left[{ }^{3} \mathrm{H}\right]$ thymidine incorporation, cell cycle progression, and the expression or activation of cell cycle regulatory proteins in PDGF-stimulated VSMCs. VSMCs cultured in serum-starved medium were stimulated with $25 \mathrm{ng} / \mathrm{mL}$ PDGF-BB, and the effect of various concentrations of clitocybin $\mathrm{A}(5-20 \mu \mathrm{M})$ on DNA synthesis by the addition of $1 \mu \mathrm{Ci} / \mathrm{mL}\left[{ }^{3} \mathrm{H}\right]$ thymidine (A), cell cycle progression (B), and PCNA protein by SDS-PAGE followed by immunoblot using antibodies for PCNA (C) were measured. Data represent the mean \pm S.E.M. from 4 different sets of experiments. $* P<0.05$ and $* * P<0.01$ vs. VSMCs stimulated with PDGF-BB alone.
Effects of clitocybin A on the expression of cell cycle regulatory proteins

To clarify whether this inhibition involves the regulation of cell cycle-related proteins, we assessed G1checkpoint proteins in clitocybin A-treated cell cycle arrest. As shown in Fig. 3, clitocybin A significantly decreased the level of CDK2, cyclin E, CDK4, and cyclin $\mathrm{D} 1$. Therefore, these results indicate that clitocybin A regulates the activity of G1 and S phase-related G1checkpoint proteins in association with its cell cycle arrest effects in VSMCs.

Effect of clitocybin A on PDGF-R $\beta, P I 3 K / A k t, E R K 1 / 2$, and PLC- $\gamma 1$ activation

To investigate the inhibitory mechanism of clitocybin A on VSMCs proliferation, we examined whether clitocybin $\mathrm{A}$ is involved in the activation of PDGF-R $\beta, \mathrm{PI} 3 \mathrm{~K} /$ Akt, ERK1/2, and PLC- $\gamma 1$ signaling. In our previous studies, we determined the maximum phosphorylation in $1 \mathrm{~min}$ for PDGF-R $\beta, 5 \mathrm{~min}$ for ERK1/2 and PLC- $\gamma 1$, and $15 \mathrm{~min}$ for Akt by PDGF-BB $(25 \mathrm{ng} / \mathrm{mL})$ stimulation of VSMCs. As shown in Fig. 4, clitocybin A did not activate PDGF-R $\beta$, ERK1/2, or PLC- $\gamma 1$. However, clitocybin A inhibited PI3K and Akt phosphorylation induced by PDGF-BB in a concentration-dependent manner, with inhibition of $58.7 \%(P<0.01, \mathrm{n}=3), 67.8 \%(P<0.01$, $\mathrm{n}=3)$, and $71.4 \%(P<0.01, \mathrm{n}=3)$ for PI3K phosphorylation and $55.0 \%(P<0.01, \mathrm{n}=3), 83.3 \%(P<0.01$, $\mathrm{n}=3)$, and $89.2 \%(P<0.01, \mathrm{n}=3)$ for Akt phosphorylation at 5,10 , and $20 \mu \mathrm{M}$, respectively (Fig. 4). These results indicate that the PI3K/Akt-mediated signaling pathway is involved in the antiproliferative action of clitocybin A.

\section{Effect of clitocybin A on PI3K/Akt pathway}

To confirm whether inhibiting PI3K/Akt pathways can reach a synergistic inhibition on VSMCs proliferation, we examined the synergistic effects of LY294002 (a $\mathrm{PI} 3 \mathrm{~K} / \mathrm{Akt}$ pathway inhibitor) and clitocybin A when they were treated in combination. LY294002 $(1 \mu \mathrm{M})$ or clitocybin A $(2 \mu \mathrm{M})$, partially inhibited DNA synthesis; however, when they were treated in combination, synergistic inhibitory effects were shown (Fig. 5). Therefore, these results indicate that the inhibitory effect of clitocybin A on PI3K/Akt activation may be involved in the clitocybin A-induced inhibition of cell cycle progression and VSMCs proliferation.

\section{Discussion}

We reported here that clitocybin A, a ROS scavenger, had an inhibitory effect on VSMC proliferation, which was associated with inhibition of the PI3K/Akt signaling 
(A)

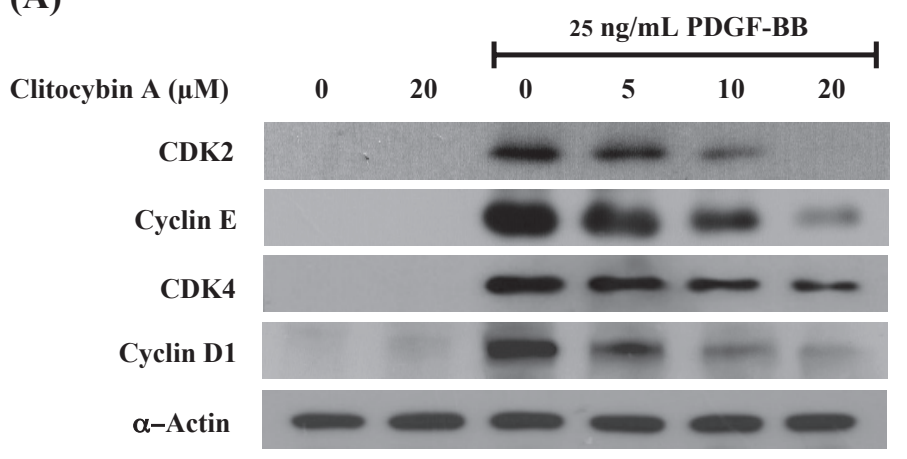

(B)
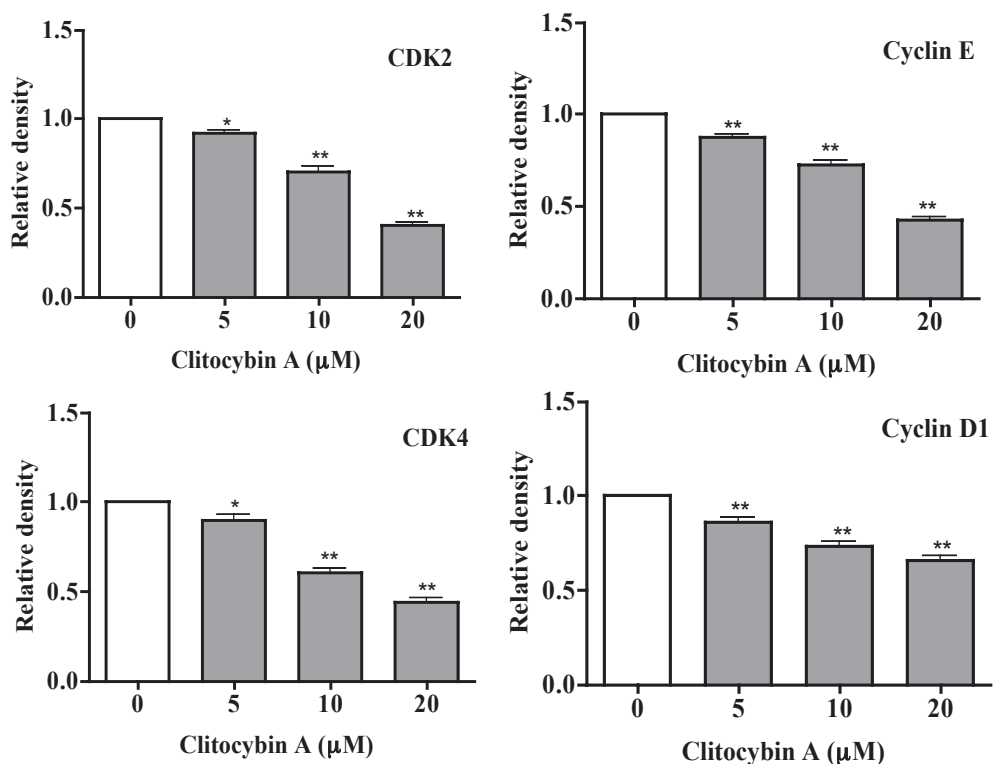

Fig. 3. Effects of clitocybin A on PDGF-BB-stimulated CDK2, CDK4, cyclin D1, and cyclin E. Quiescent VSMCs were stimulated with $25 \mathrm{ng} / \mathrm{mL}$ PDGF-BB in the presence or absence of clitocybin A at 5, 10, and $20 \mu \mathrm{M}$ for $24 \mathrm{~h}$. The cells were then lysed, and proteins were analyzed using $12 \%$ SDS-PAGE. A: Western blot analysis was performed with antibodies specific for CDK2, CDK4, cyclin D1, and cyclin E. $\alpha$-Actin was used for normalization. Representative data from 3 different experiments are presented. B: The data were quantified with densitometry and are expressed as the mean \pm S.E.M. $(\mathrm{n}=3)$. ${ }^{*} P<0.05$ and $* * P<0.01$ vs. VSMCs stimulated with PDGF-BB alone. pathways, and the inhibitory effect of clitocybin A on PI3K/Akt signaling pathways induced the suppression of DNA synthesis via G0/G1 arrest by regulating cell cyclemediated proteins such as CDK2/4 and cyclin D1/E. For the first time, we showed the antiproliferative action of clitocybin A in VSMCs, suggesting that it may be a candidate agent for the treatment of vascular restenosis and atherosclerosis.

In this study, we found that clitocybin A inhibited PDGF-BB-induced VSMCs proliferation. The activations of PI3K/Akt, ERK1/2, and PLC- $\gamma 1$ are enhanced by binding of PDGF to its tyrosine kinase and then stimulating signaling pathways $(4,15)$. Clitocybin A inhibited PDGF-BB-induced phosphorylation of PI3K/Akt, but not that of PDGF-R $\beta$, ERK1/2, and PLC- $\gamma 1$ (Fig. 4). PI3K positively regulates cell survival. Akt, a serine/ threonine protein kinase, is activated through the PI3K pathway (16). These kinases have each been implicated in VSMC proliferation, cell cycle progression, and cell survival $(16,17)$. The treatment of LY294002 with clitocybin A in VSMCs caused significant suppression of DNA synthesis (Fig. 5), indicating that this may be a synergic effect of VSMC proliferation. These findings indicated that the PI3K/Akt pathway might be a potential target for clitocybin A in VSMCs.

In the cell cycle of mammalian cells, cell division and growth are tightly controlled by regulators that act at sequential points throughout the cell cycle. The CDK2 and CDK4 are key mediators during the G1 to S phase transition of the cell cycle by forming complexes with cyclins E and D (18). These complexes phosphorylated a large number of proteins, resulting in hyperphosphorylation of $\mathrm{Rb}$, which then releases transcription factors that promote DNA synthesis $(19,20)$. The effects of clitocybin A on expressions of CDK2, cyclin E, CDK4, and cyclin D1 were investigated. Clitocybin A inhibited CDK2, cyclin E, CDK4, and cyclin D1 expressions (Fig. 3 ), indicating that cell cycle arrest in the G1-phase might 
(A)

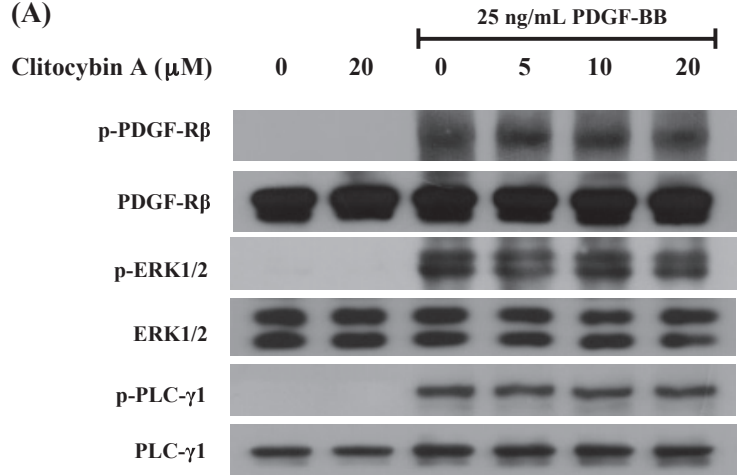

(B)
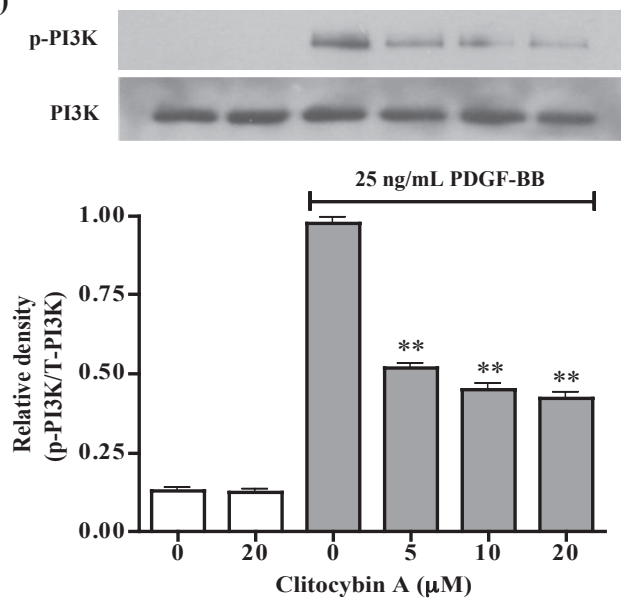

(C)

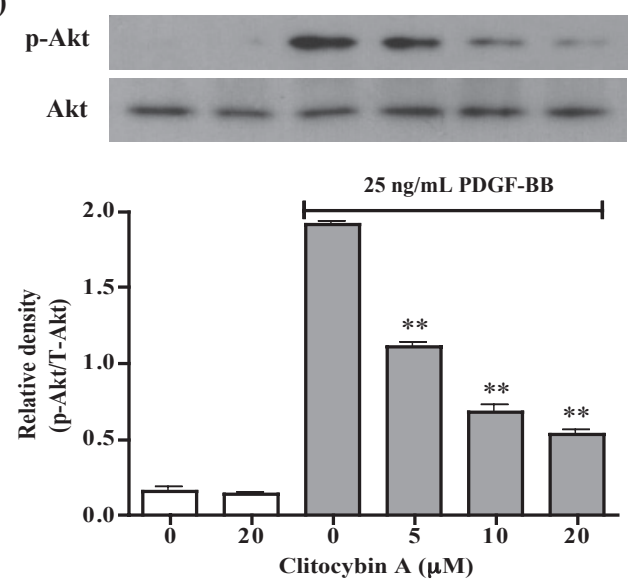

Fig. 4. Effects of clitocybin A on the PDGF-induced activation of PDGF-R $\beta$, PI3K, Akt, ERK1/2, and PLC- $\gamma 1$. VSMCs cultured in serum-free medium were stimulated with $25 \mathrm{ng} / \mathrm{mL}$ PDGF-BB, and the ability of various concentration of clitocybin $\mathrm{A}(5-20 \mu \mathrm{M})$ to reduce the PDGF-induced phosphorylation of PDGF-R $\beta$, ERK1/2, and PLC- $\gamma 1$ (A); PI3K (B); and Akt (C) were measured by SDS-PAGE and immunoblotting using primary antibodies for PDGF-R $\beta$, phosphoPDGF-R $\beta$, Akt, phospho-Akt, ERK1/2, phospho-ERK1/2, PI3K, phospho-PI3K, PLC- $\gamma 1$, and phospho-PLC- $\gamma 1$. Total amounts of PDGF-R $\beta$, Akt, ERK1/2, PI3K, or PLC- $\gamma 1$ were used for normalization and immunoblots were analyzed by densitometry; the values are given as a percentage of the control. Data were quantified with densitometry and are expressed as the mean \pm S.E.M. $(\mathrm{n}=3) .{ }^{* *} P<0.01$ vs. VSMCs stimulated with PDGF-BB alone.

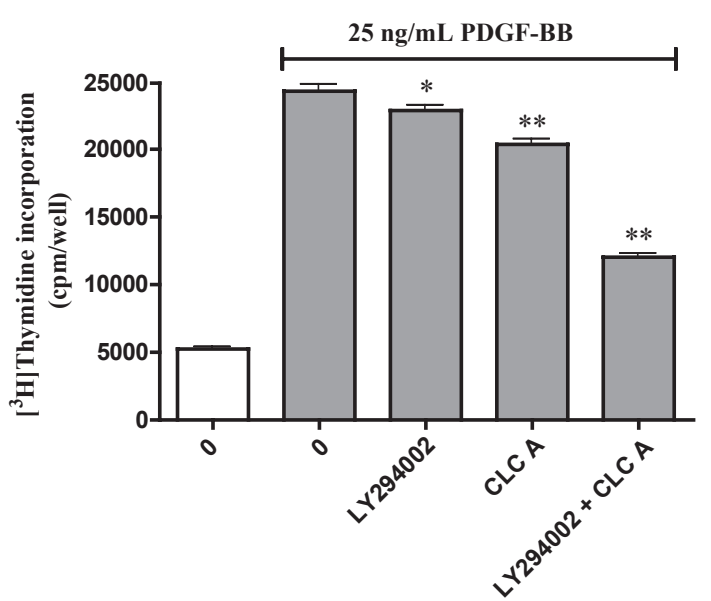

Fig. 5. Synergistic effect of PI3K inhibitor on suppression of cell proliferation by clitocybin A. Confluent cells were cultured in serumfree medium with $1 \mu \mathrm{M}$ LY294002 plus $2 \mu \mathrm{M}$ clitocybin A for $24 \mathrm{~h}$. The cells were then treated with $25 \mathrm{ng} / \mathrm{mL}$ PDGF-BB for $20 \mathrm{~h}$ before $1 \mu \mathrm{Ci} / \mathrm{mL}\left[{ }^{3} \mathrm{H}\right]$ thymidine was added. Four hours later, the labeling reaction was terminated and quantified using a liquid scintillation counter. Data represent the mean \pm S.E.M. from 4 different sets of experiments. $* P<0.05$ and $* * P<0.01$ vs. VSMCs stimulated with PDGF-BB alone.

be due to the downregulation of $\mathrm{CDKs} /$ cyclins complex expression (8). Therefore, the inhibition of CDK2, cyclin $\mathrm{E}, \mathrm{CDK} 4$, and cyclin D1 expressions may be necessary for cell cycle progression arrest in the early $\mathrm{G} 0 / \mathrm{G} 1$ and $\mathrm{S}$ phases of the cell cycle. To further evaluate the effects of clitocybin A on the regulation of VSMCs at the nuclear level, we examined PCNA expression level. PCNA is synthesized in the early G1- and S-phases of the cell cycle and is required for transition from the G1 to the S-phase (21). Therefore, PCNA can be employed as a marker for proliferating cells. Clitocybin A suppressed PCNA expression (Fig. 2C), suggesting that clitocybin A inhibited VSMCs proliferation by blocking G1 to S progression.

ROS have been reported to be critical signaling molecules in cell proliferation, which is important in the development of intimal thickening in atherosclerosis and restenosis $(22,23)$. Antioxidants such as $N$-acetylcysteine inhibited PDGF-BB-induced ROS production by scavenging ROS (22). In addition, a previous report indicated that an antioxidant, ROS scavenger, inhibits Akt activation in VSMCs (24) in agreement with this finding.

At the present stage, the molecular mechanism by which the clitocybin A exerts it influence on VSMCs proliferation has not been fully clarified. However, these results indicate that inhibition of the PI3K/Akt pathway induced by PDGF-BB may be involved in the clitocybin A-induced inhibition of cell proliferation and the ROS 
scavenging effect of clitocybin A may partially contribute to the inhibition of PDGF signal transduction.

Taken together, these findings provide evidence that clitocybin A inhibits PDGF-BB-induced VSMCs proliferation by inhibiting PI3K- and Akt-mediated signaling pathways. In addition, the expressions of cyclin $\mathrm{D}$, cyclin E, CDK2, and CDK4 are subsequently downregulated, and PCNA phosphorylation is inhibited, leading to G0/ G1 cell cycle arrest. Thus, clitocybin A may be a candidate antiproliferative agent for the treatment of vascular restenosis and stent implantation.

\section{Acknowledgment}

This work was supported by the National Research Foundation of Korea [NRF] grant funded by the Korea government [MEST] (MRC, 2010-0029480).

\section{References}

1 Ross R. The pathogenesis of atherosclerosis: a perspective for the 1990s. Nature. 1993;362:801-809.

2 Muto A, Fitzgerald TN, Pimiento JM, Maloney SP, Teso D, Paszkowiak JJ, et al. Smooth muscle cell signal transduction: implications of vascular biology for vascular surgeons. J Vasc Surg. 2007;45 Suppl A:A15-A24.

3 Sachinidis A, Locher R, Vetter W, Tatje D, Hoppe J. Different effects of platelet-derived growth factor isoforms on rat vascular smooth muscle cells. J Biol Chem. 1990;265:10238-10243.

4 Claesson-Welsh L. Platelet-derived growth factor receptor signals. J Biol Chem. 1994;269:32023-32026.

5 Heldin $\mathrm{CH}$, Ostman A, Ronnstrand L. Signal transduction via platelet-derived growth factor receptors. Biochim Biophys Acta. 1998;1378:F79-F113.

6 Liu C, Su T, Li F, Li L, Qin X, Pan W, et al. PI3K/Akt signaling transduction pathway is involved in rat vascular smooth muscle cell proliferation induced by apelin-13. Acta Biochim Biophys Sin. 2010;42:396-402.

7 Cui RR, Mao DA, Yi L, Wang C, Zhang XX, Xie H, et al. Apelin suppresses apoptosis of human vascular smooth muscle cells via APJ/PI3-K/Akt signaling pathways. Amino Acids. 2010;39: $1193-1200$.

8 Dzau VJ, Braun-Dullaeus RC, Sedding DG. Vascular proliferation and atherosclerosis: new perspectives and therapeutic strategies. Nat Med. 2002;8:1249-1256.

9 Braun-Dullaeus RC, Mann MJ, Sedding DG, Sherwood SW, von der Leyen HE, Dzau VJ. Cell cycle-dependent regulation of smooth muscle cell activation. Arterioscler Thromb Vasc Biol. 2004;24:845-850.
10 Sherr CJ, Roberts JM. CDK inhibitors: positive and negative regulators of G1-phase progression. Genes Dev. 1999;13: 1501-1512.

11 Kim YH, Cho SM, Hyun JW, Ryoo IJ, Choo SJ, Lee S, et al. A new antioxidant, clitocybin A, from the culture broth of Clitocybe aurantiaca. J Antibiot (Tokyo). 2008;61:573-576.

12 Moon EY, Oh JM, Kim YH, Ryoo IJ, Yoo ID. Clitocybins, novel isoindolinone free radical scavengers, from mushroom Clitocybe aurantiaca inhibit apoptotic cell death and cellular senescence. Biol Pharm Bull. 2009;32:1689-1694.

13 Chamley JH, Campbell GR, McConnell JD, Groschel-Stewart U. Comparison of vascular smooth muscle cells from adult human, monkey and rabbit in primary culture and in subculture. Cell Tissue Res. 1977; 177:503-522.

14 Park ES, Lim Y, Hong JT, Yoo HS, Lee CK, Pyo MY, et al. Pterostilbene, a natural dimethylated analog of resveratrol, inhibits rat aortic vascular smooth muscle cell proliferation by blocking Akt-dependent pathway. Vascul Pharmacol. 2010;53:61-67.

15 Blenis J. Signal transduction via MAPK kinases: proceed at your own RSK. Proc Natl Acad Sci U S A. 1993;90:5889-5892.

16 Higaki M, Shimokado K. Phosphatidylinositol 3-kinase is required for growth factor-induced amino acid uptake by vascular smooth muscle cells. Arterioscler Thromb Vasc Biol. 1999;19: 2127-2132.

17 Waltenberger J. Modulation of growth factor action. Implications for the treatment of cardiovascular diseases. Circulation. 1997; 96:4083-4094.

18 Sherr CJ, Roberts JM. CDK inhibitors: positive and negative regulators of G1-phase progression. Genes Dev. 1999;13: 1501-1512.

19 Sherr CJ. Cancer cell cycles. Science. 1996;274:1672-1677.

20 Sherr CJ. The Pezcoller lecture: cancer cell cycles revisited. Cancer Res. 2000;60:3689-3695.

21 Tomita H, Osanai T, Toki T, Maeda N, Murakami R, Chen Z, et al. Roxithromycin is an inhibitor of human coronary artery smooth muscle cells proliferation: a potential ability to prevent coronary heart disease. Atherosclerosis. 2005;182:87-95.

22 Park J, Ha H, Seo J, Kim MS, Kim HJ, Huh KH, et al. Mycophenolic acid inhibits platelet-derived growth factor-induced reactive oxygen species and mitogen activated protein kinase activation in rat vascular smooth muscle cells. Am J Transpl. 2004;4: 1982-1990.

23 Sasaki T, Maruyama H, Kase Y, Takeda S, Aburada M. Antianginal effects of lercanidipine on the vasopressin or methacholine induced anginal model in rats. Biol Pharm Bull. 2005;28: 811-816.

24 Hur KY, Seo HJ, Kang ES, Kim SH, Song S, Kim EH, et al. Therapeutic effect of magnesium lithospermate B on neointimal formation after balloon-induced vascular injury. Eur J Pharmacol. 2008;586:226-233. 